\title{
NEW APPROACH ON THE SAIGA ANTELOPES (Saiga tatarica/borealis; Bovidae) FROM THE LATE PLEISTOCENE AND HOLOCENE OF CRIMEA (SE UKRAINE)
}

\author{
MATEI M. VREMIR ${ }^{1}$
}

\begin{abstract}
The present paper is a short review of the knowledge regarding the fossil saiga antelopes from the Pleistocene and Holocene of Crimea, in the context of the general taxonomic and phylogenetic problems in question. According to the newly discovered paleontological material from the Crimean Mountain cave-sites, a new point of view is considered.
\end{abstract}

Key words. Vertebrate paleontology; Saiga tatarica/borealis; Mammalia; Bovidae; Pleistocene; Holocene; Crimea; Ukraine.

The present day (extant) saiga antelope Saiga tatarica (LINNAEUS, 1766) is restricted to a few dry-steppes and semi-desertic areas from Central Asia, situated between the Lower Volga and Western Mongolia. In the past, especially at the end of the Pleistocene, saiga was present in much larger areas, being reported from Western Europe from England and North to the Pireenes and Alps, Eastern Europe, the Urals, NE Siberia and Beringia till Alaska and present day Canada (Kahlke, 1991).

Two extant subspecies are recognised: Saiga tatarica tatarica (LINNAEUS) a larger form, present in Eastern Europe and Central Asia, respectively Saiga tatarica mongolica BANNIKOV, 1946, a smaller form, known from the Western Mongolian Great Lakes basin. Besides their size, there are some morphological differences observed mainly on skull and horns (Bannikov, 1963).

Middle-Late Pleistocene fossil saigas were earlier allocated to different species: Saiga binagadensis ALEKPEROVA, 1955 (Eemian of Baku area, Transcaucasia), Saiga prisca NeHRING, 1891 (Weichselian of Moravia), Saiga richei FRICK, 1937 (Late Pleistocene of NE Siberia and Alaska), Saiga borealis CHERSKIY, 1876 (Late Pleistocene Eurasia) or Saiga tatarica LINNAEUS (Late Pleistocene and Holocene of Europe). There are a few studies (Bannikov, 1963; Harrington, 1981; Baryshnikov \& Tikhonov, 1989, 1994; Baryshnikov et al., 1990; Kahlke, 1991) dealing with the proper allocation of the fossil saiga antelopes of Eurasia and North America. According to this authors, there are different oppinions regarding to the sistematic position of the fossil specimens. The statute of S. binagadensis is still not very clear, on the basis of scarce and fragmentary material being considered a smaller Southern type, most probable a subspecies of $S$. tatarica (e.g. S. tatarica binagadensis). Two other Late Pleistocene species, $S$. richei and $S$. prisca are not certified, being separated on rather poor material without any clear diagnostic features. They are now considered as

'Babeş-Bolyai University, Dept. of Geology and Palaeontology, Kogălniceanu 1, 3400, Cluj-Napoca, Romania. e-mail:vremirmatyi@yahoo.co.uk 
belonging to the $S$. tatarica/borealis group. The Middle-Late Pleistocene Northern type (large form) is considered S. borealis. This species was separated from S. tatarica on the basis of the larger size as well as of some morphologic differences on skull (Baryshnikov \& Tikhonov, 1994). Because the great individual variability observed on the extant species, also the fragmentary state of fossil specimens, most of the characters used to separate these types are now considered questionable, and the Northern type is regarded by some authors as a subspecies of the extant $S$. tatarica (e.g. S. tatarica borealis). The morphological differences between the extant, respectively the Southern and Northern fossil types, are in the observed range given by Bannikov, 1946 to separate the two present day subspecies (Harington, 1981).

In the light of the most recent paleontological investigations (Vremir \& Ridush, 2002; Vremir, Kovacs \& Ridush, 2003) made in some Late Pleistocene and Holocene cave sites of the Crimean Mountains (SE Ukraine), this question could be revised, at least regarding the Crimean forms. Baryshnikov et al. (1990) published a monographic study of the Late Pleistocene saiga antelopes of Crimea, retreived from cave deposits, mainly archeological (Mousterian) sites located on the foothills of the Yayla Mountains. This large collection however is composed only by fragmentary postcranial elements and a few skull and horncore fragments, respectively a large number of isolated teeth. The authors concluded that the Crimean Late Pleistocene saiga must be regarded as a different form than the extant one, very close to $S$. borealis, but with an unclear statute (distinction on species or subspecies level).

New and exceptionally preserved Late Pleistocene and Holocene materials allow to reopen this question. On the basis of hundreds of well preserved bones, several complete skulls and mandibles as well as two almost complete skeletons, all of the morphological characters of the fossil forms are now available for study and comparison. There is an obvious decrease in size from the Late Pleistocen (Valdaian) till the Bronze age forms, however less pronounced comparatively to the recent one. Individual variability is not well expressed. Based mainly on the skull morphology there are important differences compared to the extant form, and the Late Pleistocene Crimean one can be regarded as a distinct type. More comparisons especially with fossil specimens but also recent materials, will give a much secure answer on this question.

Regarding the stratigraphic distribution of the saiga antelope in Crimea, this is present at least from the Valdaian, till historic times $\left(18^{\text {th }}\right.$ century). A quite "fresh" juvenile saiga skeleton (partial) was recently found in the entrance area of the AK4 pothole on the Chatyrdag Upper Plateau near Angar Burun peak (1430 m a.s.l.), which could indicate that the saiga possibly survived much longer in the remote mountain steppes of the Crimea (high mountain plateaus probably functined as refuge), possibly till $20^{\text {th }}$ century.

As a hypothesis to explain the morpho-dimensional differences between the extant, respectively, Crimean fossil forms, a nonequilibrum island biogeography, respectively the colonization - recurrent extinction processes as well as the palaeogeographical evolution of the region must be regarded. Probably the first arrival belongs to this distinct and widely spread Valdaian type, followed by izolation due to the rise of the Black Sea level and development of the Crimean Island (however the saigas are good swimmers, being able to cross large rivers), and possible extinction in the postglacial. A second colonization by the recent, more specialized 106 
type, posibly follows the development of the Perekop istmus in the western Azov Sea area (known as the Sivash Sea), in the last thousands of years. On the other hand, differences on the mandible and skull morphology (especially nazal and upper jaw) between the extant and Crimean fossil types, can be regarded as a consequence of adaptative transformations, induced by the environmental changes, respectivelly the izolation of the recent forms in much dryer areas. Finally, we must consider that the present day $S$. $t$. tatarica materials, used by many outhors for comparison, belong to a recent population originating from a small area of the Aral region, which at the beginning of the $20^{\text {th }}$ century was almost extinct (several hundred specimens in 1920th), forming the stock of the present day population of several millions individuals spread all over Central Asia. Older papers also used recent comparative material from the "South Uralian steppes" situated between the Caspian and Azov seas (Kazakhstan).

A mozaic-adaptative evolution as well as radiations during the optim-ecological periods could be responsible for the diversity on morphology in different saiga types recognised on the fossil record (as in the case of the two extant subspecies). A distinction on subspecies level (considering the timespan since the last areal fragmentation) for the Late Pleistocene - Holocene forms could be the most appropriate, however some new and well preserved materials from other Eurasian sites are still needed to answer this question.

\section{REFERENCES}

Alekperova, N. A., 1955, Iskopayemaya binagasinkaya sayga. In: Binagadinskoye Mestonskhozdeniye Chervartichnory Fauna i Flory, 4. Trudy Estest,-lstorri Musei G. Zarbadi, Akademija Nauka Azerbaidzan SSR, no. 10, pp. 10-64.

Bannikov, A. G., 1963, Die Saiga-Antilope (Saiga tatarica L.). A. Ziemens verlag, pp. 143, Wittemberg.

Baryshnikov, G. F., Tikhonov A. N., 1989, Saiga in the Pleistocene of Eurasia. Fifth International Theriological Congress., Abstract of Papers and Posters. 2, pp. 625-626, Roma.

Baryshnikov, G. F., Kasparov, A. K., Tikhonov, A. H, 1990, Saiga of the Paleolithic of the Crimea. Proceedings of the Zoological Institute. USSR Academy of Science. vol. 212, pp. 3-48. Leningrad

Baryshnikov, G. F., Tikhonov, A. N., 1994, Notes on skulls of Pleistocene saiga of Northern Asia. Historical Biology, vol. 8, pp. 209-234.

Harington, C. R., 1981, Pleistocene Saiga Antelopes in North America and their Paleoenvironmental Implications. In: Mahaney, W. C. (ed.): Quaternary Paleoclimate. pp. 193-225, University of East Anglia, Norwich.

Kalkhe, R-D., 1991, Pleistocene Distributional and Evolutinary History of the genus Saiga Gray, 1843 (Mammalia, Artiodactyla, Bovidae) in the Palaearctic. Vertebrata PalAsiatica, vol. 24, no. 4, pp. 323-326.

Vremir, M., Ridush, B., 2002, Recent paleontological investigations in some caves of the Crimean mountain-range (SE Ukraine). Theoretical and Applied Karstology vol. 15, pp. 125-132, Bucharest.

Vremir, M., Kovacs, A. \& Ridush, B., 2003, Natural Trap-caves on the Chatyrdag Plateau (Crimea, SE Ukraine): The Emine Bair Khosar "Mega-trap" Recent advances in the Quaternary paleoenvironmental and paleoclimatic research in Romania and neighboring countries. Abstract and Extended abstracts of the International Workshop (June 24-28, 2003, Cluj-Napoca, Romania, B. Onac eds.), pp. 41-44, Cluj-Napoca. 


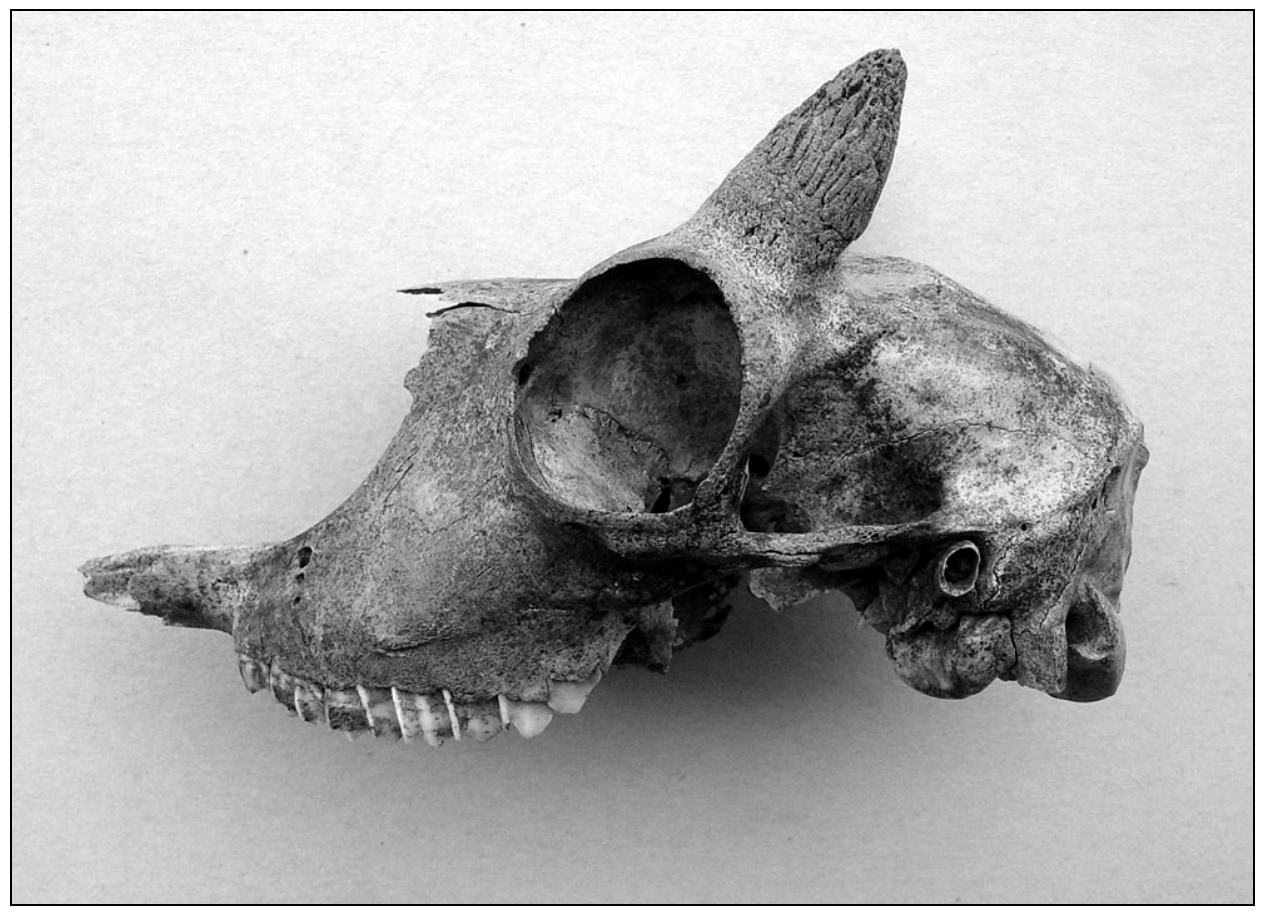

Fig. 1. Saiga tatarica/borealis, EBK Bc 456- skull of atypical (horned) subadult female from the Middle Valdaian/Bryansk interstadial (approx. $40 \mathrm{Ky} \mathrm{BP}$ ) of Chatyr-dag plateau, Crimea. Length of horncores $-40 \mathrm{~mm}$. Length of skull $-192 \mathrm{~mm}$. According to Bannikov (1963), respectively Baryshnikov $\mathrm{G}$. (pers. comm.) this condition is rarely recorded in the present day populations, the horned females being reported in 1:10.000 individuals 